\title{
Fatty acid profile and lambs' meat quality fed with different levels of crude glycerin replacing corn
}

\section{Perfil de ácidos graxos e qualidade da carne de cordeiros alimentados com diferentes níveis de glicerina bruta em substituição ao milho}

\author{
Fabíola Cristine de Almeida Rego ${ }^{1 *}$; Mônica Chaves Françozo ${ }^{2}$; \\ Agostinho Ludovico ${ }^{3}$; Filipe Alexandre Boscaro de Castro ${ }^{4}$; Marilice Zundt ${ }^{5}$; \\ Camila Roberta Lupo'; Laís Belan²; Luiz Fernando Coelho Cunha Filho'; \\ Joice Sifuentes dos Santos ${ }^{3}$; Caliê Castilho ${ }^{5}$
}

\begin{abstract}
This study aimed to evaluate the Texel lambs' meat quality fed with increasing levels of crude glycerin $(0,7,14$, and $21 \%$ of dry matter) in the diet. Thirthy-two-two non-castrated male Texel lambs were used, with initial weight of $15.9 \pm 4.1 \mathrm{~kg}$, using a completely randomized design with four treatments and eight repetitions, per treatment. Upon reaching the average weight of $35 \mathrm{~kg}$, the animals were slaughtered. The meat chemical composition was similar among treatments $(\mathrm{P}>0.05)$ and total lipids

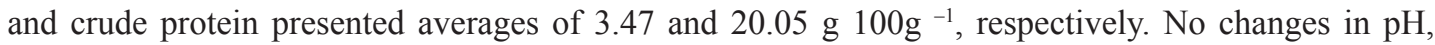
marbling, color, and water loss under pressure were observed. The shear force did not change among treatments and the texture can be considered soft, with average values of $5.48 \mathrm{kgf}$. There was a linear $(\mathrm{P}<0.05)$ decrease in odor values by the addition of glycerin and no significant differences $(\mathrm{P}>0.05)$ were observed for the attributes flavor, tenderness, juiciness, and overall acceptance among treatments. Fatty acids in higher proportions in the meat lamb were to C18:1n-9 (1298.90 mg 100 $\left.\mathrm{g}^{-1}\right), \mathrm{C} 16: 0$ (709.07 $\left.\mathrm{mg} 100 \mathrm{~g}^{-1}\right)$ and $\mathrm{C} 18: 0\left(433.30 \mathrm{mg}^{100 \mathrm{~g}^{-1}}\right)$, with percentages of $42.72,23.07$ and $14.35 \%$, respectively. Significant difference according to the glycerin level in the diet was observed only for the margaric

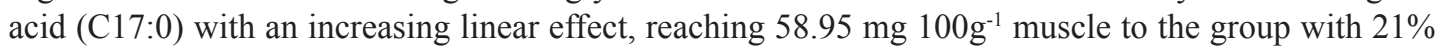
crude glycerin, corresponding to $1.77 \%$ of total fatty acids. The other fatty acids did not change, and provided a satisfactory result for conjugated linoleic acid (CLA), totaling about $6.1 \mathrm{mg} 100 \mathrm{~g}^{-1}$ muscle, corresponding to $0.21 \%$ of total lipids. The use of glycerin in the diet for finishing lambs does not alter the characteristics of the meat, maintaining the product quality for consumption.
\end{abstract}

Key words: Chemical composition. Conjugated linoleic acid. Sensory evaluation.

\footnotetext{
${ }^{1}$ Profs., Mestrado em Saúde e Produção de Ruminantes, Universidade Norte do Paraná, UNOPAR, Arapongas, PR, Brasil. E-mail: fabiolaregogrecco@gmail.com; luiz.cunha@unopar.br

2 Discentes de Mestrado em Saúde e Produção de Ruminantes, UNOPAR, Arapongas, PR, Brasil. E-mail: monicacf.vet@hotmail. com; lais_belan@hotmail.com; camilupo@gmail.com

3 Profs., Mestrado em Ciência e Tecnologia do Leite e Derivados, UNOPAR, Londrina, PR, Brasil. E-mail: agostinho.ludovico@, unopar.br; joice.sifuentes@unopar.br

${ }^{4}$ Prof. Dr., Universidade Estadual de Londrina, UEL, Londrina, PR, Brasil. E-mail: fabcastro76@yahoo.com.br

5 Prof $^{\text {as }}$, Programa de Pós-Graduação Ciência Animal, Universidade do Oeste Paulista, UNOESTE, Presidente Prudente, SP, Brasil. E-mail: mari@unoestebr; calie@unoeste.br

* Author for correspondence
} 


\title{
Resumo
}

\begin{abstract}
Objetivou-se avaliar a qualidade da carne de cordeiros Texel alimentados com níveis crescentes de glicerina bruta $(0,7,14$ e $21 \%$ da matéria seca) na dieta. Trinta e dois cordeiros Texel machos não castrados foram avaliados, com peso inicial de 15,9 $\pm 4,1 \mathrm{~kg}$, em delineamento inteiramente casualizado, com quatro tratamentos e oito repetições. Ao atingir o peso médio de $35 \mathrm{~kg}$, os animais foram abatidos. A composição química da carne foi similar entre os tratamentos e as medias de lipídios totais e proteína bruta foram 3,47 e 20,05 g $100 \mathrm{~g}^{-1}$, respectivamente. Não houve variações nos valores de $\mathrm{pH}$, marmoreio, cor e perda de água por pressão. A força de cisalhamento não variou entre os tratamentos e a textura da carne pode ser considerada macia, com valores médios de 5,48 kg-f. Houve decréscimo linear nos valores de odor em função da adição de glicerina bruta e não houve diferença significativa para sabor, maciez, suculência, e aceitação geral entre os tratamentos. Os ácidos graxos encontrados em maiores proporções na carne de cordeiros foram C18:1n-9 (1298,90 mg 100g $\left.{ }^{-1}\right)$, C16:0 $\left(709,07 \mathrm{mg} \mathrm{100g}^{-1}\right) \mathrm{e}$ C18:0 (433,30 mg 100 $\mathrm{g}^{-1}$ ), com porcentagens de 42,72, 23,07 e 14,35\%, respectivamente. Foi observada diferença significativa em função do nível de glicerina na dieta apenas para o ácido margárico (C17:0), com um efeito linear crescente, atingindo $58,95 \mathrm{mg} 100 \mathrm{~g}^{-1}$ de carne para o grupo com $21 \%$ de glicerina bruta, o que corresponde a $1,77 \%$ do total ácidos graxos. O restante dos ácidos graxos não se alteraram e proporcionaram um resultado satisfatório para o ácido linoleico conjugado (CLA), somando cerca de 6,1 mg $100 \mathrm{~g}^{-1}$ de carne, correspondendo a $0,21 \%$ do total de lipídeos. O uso de glicerina na dieta de cordeiros em terminação não altera as características da carne, mantendo a qualidade do produto para consumo.

Palavras-chave: Composição química. Ácido linoleico conjugado. Análise sensorial da carne.
\end{abstract}

\section{Introduction}

Sheep farming is an important livestock activity in Brazil that extends throughout the country, being a source of income and livelihood, which is currently undergoing reorganization (VIANA et al., 2013).

Animal feed has the highest cost of cattle industry, with a limited potential for economic efficiency. Therefore, the by-products generated in the agribusiness may be economically viable alternatives that can replace partially or totally roughage and concentrate, not affecting the performance and the animals' feed efficiency. The citrus pulp and cottonseed are examples of byproducts used in ruminant feed.

Recently, the glicerin, which is a biodiesel production by-product, has been increasing interest for ruminant nutrition. This by-product is produced in a ratio of about 1 unit for 9 units of biodiesel produced, containing about $80 \%$ glicerol (propane1,2,3-triol or 1,2,3-propanetriol) and is used mainly as energy source in animal nutrition. Also, it is easily fermented by ruminal microbes, producing large proportion of propionate (AVILA et al., 2011;
BERGNER et al., 1995), or absorbed directly into the portal blood via rumen or small intestine and converted to glucose and lipids in the ruminant metabolism (KRISTENSEN; RAUN, 2007).

Ruminants meat contains higher levels of saturated fatty acids and less polyunsaturated acids: saturated ratio, when compared to that of monogastric animals, and this difference results from the ruminal biohydrogenation of unsaturated fatty acids and fatty acids synthesis by rumen bacteria. Also, availability of precursors for fatty acids synthesis and changes in the endogenous metabolism can affect the fatty acids profile in the lipids (FRENCH et al., 2000).

The determination of the fatty acids profile is of great importance, particularly regarding the content of essential fatty acids, saturated, monounsaturated, polyunsaturated fatty acids, and more recently specific fatty acids such as the margaric and the conjugated linoleic acids (CLA), for their possible health benefits (JENKINS et al., 2015; CALDER, 2015; ALVES et al., 2012).

The fatty acid profile can be influenced by the diet to which the animal is subjected, whose 
formulation can include lipid sources or precursors and additives, as well as changes in the forage: concentrate ratio. Therefore, the aim of this study was to evaluate the fatty acids profile and the quality of lamb meat terminated in confinement, fed with increasing levels of crude glycerin.

\section{Material and Methods}

The experiment was performed at the University North of Paraná (UNOPAR) in Arapongas, PR, Brazil (23 25'08' S 51 25' 26" W). The field phase was carried out from September to December 2012. The total experimental period was 88 days and the first 14 days were of adaptation to experimental diets. Before starting the experiment, the animals were dewormed. The study was in accordance with the ethical principles of animal experimentation ethics committee for animal use from UNOPAR (CEA 004/12).
Thirty-two Texel male sheep were used, aged about 60 days with mean initial weight of $15.9 \pm$ $4.1 \mathrm{~kg}$ housed in groups of eight animals in four covered pens equipped with troughs for food and water. The experimental design was completely randomized with four treatments consisting of glycerin levels of $0,7,14$, and $21 \%$ of dry matter (DM) in replacement of corn, and eight repetitions per treatment. The lambs received diets (Table 1) formulated to produce a mean daily weight gain of $250 \mathrm{~g}$ (NRC, 2007), with forage:concentrate ratio of 60:40. Bromatological analyzes of the diets (Table 1) were performed according to the methodologies described in Mizubuti et al. (2009).

Glycerin was acquired in the Company Parana BioPar Bioenergia (Rolândia, PR, Brazil), and its physicochemical characteristics are shown in Table 2.

Table 1. Percentage of ingredients and physicochemical composition of the experimental diets $\left(\mathrm{g} \mathrm{kg}^{-1} \mathrm{DM}\right)$ of lambs finished in confinement with different levels of crude glycerin.

\begin{tabular}{lcccc}
\hline & \multicolumn{3}{c}{ Glycerin levels in the diet in replacement of corn (\%) } \\
\cline { 2 - 4 } & 0 & 7 & 14 & 21 \\
\hline Ingredients $\left(\mathrm{g} \mathrm{kg}^{-1}\right)$ & 413 & 413 & 413 & 413 \\
\hline Corn silage & 377 & 292 & 208 & 123 \\
Corn & 169 & 184 & 198 & 213 \\
Soybean meal & 27 & 27 & 27 & 27 \\
Mineral salt & 14 & 14 & 14 & 14 \\
Limestone & 0.0 & 70 & 140 & 210 \\
Glycerine & & & & \\
\hline Chemical Composition $\left(\mathrm{g} \mathrm{kg}^{-1}\right)$ & 520 & 504 & 505 & 520 \\
\hline Dry matter & 56 & 64 & 60 & 62 \\
Mineral matter & 24 & 20 & 18 & 13 \\
Ether extract & 335 & 316 & 317 & 308 \\
Neutral detergent fiber & 116 & 113 & 107 & 107 \\
Acid detergent fiber & 781 & 767 & 757 & 759 \\
Total Carbohydrates & 444 & 448 & 441 & 455 \\
Non-fibrous carbohydrates & 155 & 146 & 145 & 154 \\
Crude Protein & 96.9 & 91.7 & 145 & 148 \\
Neutral detergent insoluble protein & 216 & 122 & 151 & 138 \\
Acid detergent insoluble protein & 26 & 24 & 17 & 26 \\
Lignin & 612 & 630 & 634 & 619 \\
Total digestible nutrients* & & & \\
\hline
\end{tabular}

* Values estimated according to NRC (2001). 
Table 2. Physicochemical characteristics of glycerin.

\begin{tabular}{lc}
\hline Determination & Levels \\
\hline Water (\%) & 6.4 \\
Glycerol (\%) & 78 \\
$\mathrm{pH}($ scale) & 6.64 \\
$\mathrm{NaCl}(\%)$ & 0.65 \\
Methanol (\%) & 0.6 \\
\hline
\end{tabular}

Source: Parana Biopar Bioenergia.

The slaughter was carried out when the animals reached $35 \mathrm{~kg}$ of live weight (LW), through concussion and subsequent evisceration. Before slaughter, animals were weighed and then subjected to a 16-hour fast (no solid food) and then weighed again to obtain body weight at slaughter (BWS). Feet, head and internal components were removed; then the carcass was weighed, obtaining the hot carcass weight (HCW). After slaughter, the carcasses were transported to a cold chamber at $4^{\circ} \mathrm{C}$ for 24 hours. After the cooling period, the carcasses were weighed to obtain the cold carcass weight $(\mathrm{CCW})$.

After cooling, the whole Longissimus dorsi muscle was removed from the carcass, which was sliced in eight steaks, being three steaks $(3 \mathrm{~cm})$ for shear force; two steaks $(3 \mathrm{~cm})$ for sensory evaluation; one steak $(2 \mathrm{~cm})$ for color, $\mathrm{pH}$, and water loss under pressure (WLP), one steak $(2 \mathrm{~cm})$ for chemical composition analysis, and one steak $(2 \mathrm{~cm})$ for fatty acid profile. Color, $\mathrm{pH}$, marbling, and water loss under pressure were determined in the same day, soon after sampling ( $24 \mathrm{~h}$ after slaughter), while the other samples were frozen for later analysis.

The WLP was performed by the method of pressure through filter paper (CAÑEQUE; SAÑUDO, 2000). The meat $\mathrm{pH}$ reading was held in the Longissimus dorsi muscle with the aid of a portable digital $\mathrm{pH}$ meter, TESTO ${ }^{\circledR} 205$, with insertion electrode and resolution of $0.01 \mathrm{pH}$ units (BRESSAN et al., 2001).

The marbling rate was determined subjectively using photographic standards (AMSA, 2001), assigning scores from 1 to $10(1=$ marbling traits and abundant marbling $=10$ ), by comparing them with the standard panel for photographic marbling.

Color measurements were performed 30 minutes after meat slicing into steaks. The color was analyzed by Minolta ${ }^{\circledR}, \mathrm{CR}-10$ model, portable colorimeter to evaluate the parameters L* (luminosity), a* (redgreen component) and $\mathrm{b}^{*}$ (yellow-blue component) expressed in the CIELAB color system. A D65 illuminant was used at an observation angle of $10^{\circ}$ and with a measuring area of $8 \mathrm{~mm}$. Three measurements were performed for each sample, and the average of these readings represented the coordinates L*, a* and b* (HOUBEN et al., 2000). With these values, the hue angle $\left(\mathrm{h}^{*}\right)$ was calculated using equation $\mathrm{h}^{*}=\tan ^{-1}\left(\mathrm{~b}^{*} / \mathrm{a}^{*}\right)$ and the saturation index or chroma $\left(\mathrm{c}^{*}\right)$ using the equation $\mathrm{c}^{*}=$ $\left(\mathrm{a}^{* 2}+\mathrm{b}^{* 2}\right)^{0.5}$.

The samples were weighed frozen and after thawing $\left(2 \pm 2^{\circ} \mathrm{C}\right.$ for $24 \mathrm{~h}$ ), and the weight loss during thawing was determined by the ratio of the thawed sample weight and the frozen sample weight multiplied by 100 . Then, the meat was cooked in an electric furnace, for 10 minutes, turned over and baked for additional 10 minutes. The weight loss during cooking was calculated by ratio of the thawed sample weight and the cooked sample weight, multiplied by 100 (AMSA, 1995).

The shear force was measured objectively using a Texture Analyzer TA TX-2 (Godalming, UK), and sampling was performed using a cylindrical steel sampler. Three steaks were used per animal, and two sub-samples of approximately $1.25 \mathrm{~cm}$ 
thick and $2.5 \mathrm{~cm}$ height were taken from each steak and sheared once, giving a total of six readings per animal (WHIPPLE et al., 1990).

Sensory evaluation was performed by a panel with 11 trained assessors in one session. A structured numerical scale from 1 to 9 (1 unacceptable and 9 extremely acceptable) was used for overall acceptance test; for the parameters odor and juiciness, scales ranging from 1 to 5 were used (odor: 1 none and 5 extremely intense; juiciness: 1 none and 5 high juiciness); for the parameter softness, a scale ranged from one to seven (1 very hard and 7 very soft) was used. Samples were baked in a preheated oven at $180{ }^{\circ} \mathrm{C}$ until they reached an internal temperature of $72^{\circ} \mathrm{C}$. The assessors received four samples, being one of each treatment in a complete randomized order (ABNT, 1993). Samples were served to the participants individually inside disposable plastic cups that were coded by three-digit numbers.

To determine the chemical composition, after thawing in the refrigerator for $24 \mathrm{~h}$, the samples were ground and placed in a forced air oven at 105 ${ }^{\circ} \mathrm{C}$ per $24 \mathrm{~h}$. They were later processed in a Wiley mill ( $1 \mathrm{~mm}$ sieve) to determine the crude protein, moisture and ash level (AOAC, 2005).

The lipids extraction was made with a mixture of chloroform, methanol, and water, respectively (2:2:1.8 v/v/v), according to Bligh and Dyer (1959). The transesterification of the total lipid fatty acids was performed according to Maia and RodriguezAmaya (1993). Fatty acids esters were separated on a gas chromatograph (Thermo), ultra-trace model 3300, equipped with a flame ionization detector and a fused silica capillary column CP - 7420 (Select FAME, $100 \mathrm{~m}$ long, $0.25 \mathrm{~mm}$ internal diameter and $0.25 \mu \mathrm{m}$ cyanopropyl). The $\mathrm{H}_{2}$ flow (carrier gas) was $1.2 \mathrm{~mL} \mathrm{~min}^{-1}$, with $30 \mathrm{~mL} \mathrm{~min}^{-1}$ of $\mathrm{N}_{2}$ (make up gas), and 35 and $300 \mathrm{~mL} \mathrm{~min}^{-1}$ for $\mathrm{H}_{2}$ and synthetic air to the flame detector, respectively. The injected volume was approximately $2.0 \mathrm{uL}$, using 1:80 sample split mode, with injector and detector temperatures at 220 and $230^{\circ} \mathrm{C}$, respectively, and column temperature at $165^{\circ} \mathrm{C}$ for $18 \mathrm{~min}$, and then up to $235^{\circ} \mathrm{C}$, at a rate of $4^{\circ} \mathrm{C} \mathrm{min}^{-1}$, held for 14.5 min. The fatty acids percentages were determined by integration of the peak areas by the Software Chronquest version 5.0. The fatty acids were quantified by internal standardization in $\mathrm{mg} \mathrm{g}^{-1}$ of total lipids, using tricosanoic acid methyl ester as standard (23:0).

The statistical analysis of all variables studied was performed by analysis of variance and regression analysis when significant at $5 \%$ probability level, using the 9.2 version of SAS (2002).

\section{Results and Discussion}

No significant effects $(\mathrm{P}>0.05)$ of the crude glycerin addition were observed for moisture, protein, ash and total lipids (Table 3). Moisture

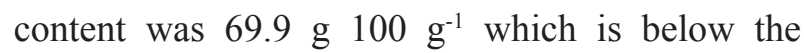
findings of Zeola et al. (2004), who found $75.6 \mathrm{~g}$ $100 \mathrm{~g}^{-1}$, but close to the findings of Barros et al. (2015), who also evaluated increasing levels of crude glycerin on diet and found values ranging

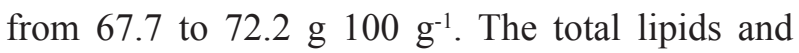
crude protein levels averaged 3.47 and $20.05 \mathrm{~g} \mathrm{~kg}^{-1}$, respectively (Table 3 ) and are close to the values obtained by Ortiz et al. (2005), being consistent with good quality meat, and considered acceptable in the literature. According to Osório and Osório (2003), the high total lipids can negatively affect meat product, once consumers have certain restrictions on the ruminants fat, mainly sheep, due to the high levels of saturated fatty acids. Studies have shown that the lipid levels of lamb meat can present great variation, especially when animals are subjected to distinct diets, such as the findings of Zeola et al. (2004) using different concentrate levels (60, 45 , and $30 \%$ ), or diets containing different sources of roughage (PONNAMPALAM et al., 2001). However, in this study, the crude glycerin levels did not significantly affect meat lipids. Ash content

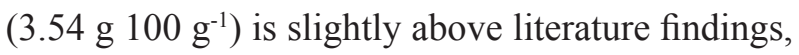

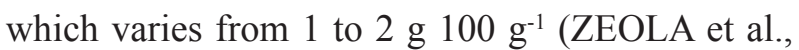
2004; PRATA; FUKUDA, 2001). 
Table 3. Means and standard error values of proximate composition of Longissimus dorsi muscle of lambs finished in confinement fed with different glycerin levels.

\begin{tabular}{lccccccc}
\hline \multirow{2}{*}{$\begin{array}{c}\text { Proximate composition } \\
\text { g 100g }{ }^{-1}\end{array}$} & \multicolumn{2}{c}{ Glycerin levels in the diet in replacement of corn (\%) } & \multirow{2}{*}{ Mean } & \multirow{2}{*}{${ }^{1} \mathrm{CV}$} & \multirow{2}{*}{${ }^{2} \mathrm{P}$} \\
\cline { 2 - 5 } & 0 & 7 & 14 & 21 & & & \\
\hline Crude protein & $22.02 \pm 1.29$ & $19.66 \pm 9.1$ & $18.76 \pm 15.6$ & $19.90 \pm 9.3$ & 20.05 & 16.80 & 0.30 \\
Moisture & $69.98 \pm 1.87$ & $69.88 \pm 17.0$ & $70.32 \pm 13.7$ & $69.73 \pm 41.0$ & 69.99 & 13.35 & 0.99 \\
Ashes & $3.83 \pm 0.46$ & $3.49 \pm 0.91$ & $3.28 \pm 1.56$ & $3.54 \pm 0.93$ & 3.54 & 22.47 & 0.19 \\
Total lipids & $3.02 \pm 0.86$ & $3.46 \pm 0.27$ & $3.43 \pm 0.14$ & $3.95 \pm 0.23$ & 3.47 & 39.22 & 0.67 \\
\hline
\end{tabular}

${ }^{1} \mathrm{CV}=$ Coefficient of variation; ${ }^{2} \mathrm{P}=$ Probability.

The inclusion of crude glycerin did not cause significant differences $(\mathrm{P}>0.05)$ on the qualitative characteristics of meat, with mean $\mathrm{pH}$ values of 5.63, and color components $\mathrm{L}^{*}, \mathrm{a}^{*}, \mathrm{~b}^{*}, \mathrm{c}^{*}$ and $\mathrm{h}^{*}$ of $41.92,13.22,8.45,32.81$ and 15.73 respectively (Table 4). Warris (2003) presented values of the color parameters from 30.03 to 49.47 for $\mathrm{L}^{*}, 8.24$ to 23.53 for the coordinate $\mathrm{a}^{*}$; and 3.38 to 11.10 for $b^{*}$. The results observed in the yellow intensity (*b) were similar to those found for Santa Ines lambs, which indicate values ranging from 7.0 to 7.9 (SOUSA et al., 2016), evaluating different food restriction levels.

Table 4. Means and standard error values of $\mathrm{pH}$, luminosity (L), green-red component (a), blue-yellow component (b), chroma (c), hue (h), water loss under pressure (WLP), shear force (SF), water losses on thawing (WLT) and cooking losses (CL) of the Longissimus dorsi muscle of lambs finished in confinement with different levels of crude glycerin.

\begin{tabular}{lccccccc}
\hline \multirow{2}{*}{ Parameters } & \multicolumn{9}{c}{ Glycerin levels in the diet in replacement of corn (\%) } & \multirow{2}{*}{ Mean } & ${ }^{1} \mathrm{CV}$ & ${ }^{2} \mathrm{P}$ \\
\cline { 2 - 5 } & 0 & 7 & 14 & 21 & & & \\
\hline $\mathrm{pH}$ & $5.70 \pm 0.06$ & $5.58 \pm 0.03$ & $5.60 \pm 0.04$ & $5.65 \pm 0.06$ & 5.63 & 2.65 & 0.45 \\
Marbling & $2.14 \pm 0.34$ & $1.71 \pm 0.28$ & $2.37 \pm 0.37$ & $1.50 \pm 0.18$ & 1.93 & 0.46 & 0.21 \\
$\mathrm{~L}$ & $41.45 \pm 0.84$ & $42.88 \pm 1.44$ & $42.27 \pm 1.19$ & $41.14 \pm 1.24$ & 41.92 & 7.47 & 0.70 \\
$\mathrm{a}$ & $12.70 \pm 0.85$ & $12.84 \pm 0.74$ & $13.65 \pm 0.80$ & $13.68 \pm 0.46$ & 13.22 & 14.70 & 0.61 \\
$\mathrm{~b}$ & $8.42 \pm 0.34$ & $8.82 \pm 0.40$ & $8.53 \pm 0.35$ & $8.11 \pm 0.34$ & 8.45 & 11.13 & 0.54 \\
$\mathrm{~h}\left({ }^{\circ}\right)$ & $34.06 \pm 1.69$ & $34.59 \pm 1.07$ & $32.36 \pm 2.06$ & $30.64 \pm 0.73$ & 32.81 & 12.44 & 0.23 \\
$\mathrm{c}$ & $15.18 \pm 0.80$ & $15.59 \pm 0.79$ & $16.15 \pm 0.68$ & $15.91 \pm 0.50$ & 15.73 & 11.56 & 0.78 \\
WLP (\%) & $22.03 \pm 1.54$ & $26.13 \pm 1.98$ & $26.00 \pm 0.89$ & $25.00 \pm 1.67$ & 24.99 & 16.57 & 0.15 \\
SF (KgF) & $5.52 \pm 0.39$ & $5.88 \pm 0.34$ & $5.31 \pm 0.46$ & $5.11 \pm 0.28$ & 5.48 & 17.87 & 0.43 \\
WLT (\%) & $5.77 \pm 0.63$ & $5.34 \pm 0.91$ & $5.46 \pm 1.41$ & $6.10 \pm 0.85$ & 5.68 & 15.54 & 0.94 \\
CL (\%) & $28.71 \pm 1.01$ & $29.51 \pm 1.34$ & $27.47 \pm 1.46$ & $27.81 \pm 1.11$ & 28.33 & $11, .98$ & 0.67 \\
\hline
\end{tabular}

${ }^{1} \mathrm{CV}=$ Coefficient of variation; ${ }^{2} \mathrm{P}=$ Probability.

The mean $\mathrm{pH}$ value was 5.63 (Table 4), which is close to the findings of Lage et al. (2010), who also evaluated the use of different levels of crude glycerin in lambs diet, and found on average $\mathrm{pH}$ 6.0. The final $\mathrm{pH}$ after $24 \mathrm{~h}$ of cooling is one of the parameters that can interfere with the meat quality (sensory characteristics such as tenderness and water holding capacity). The $\mathrm{pH}$ average values found in this study are within the expected normal range between 5.66 to 5.78 , after 24 h of slaughter, which is consistent with the data obtained in this study (SAÑUDO, 1992). If the $\mathrm{pH}$ remains high, with values above 6.0 , the meat presents a problem known as DFD (dark, firm and dry) having a dark color, characterized by high water holding capacity and reduced shelf life (APPLE et al., 1995).

No significant differences were observed $(\mathrm{P}>0.05)$ for the water loss under pressure among glycerin crude levels, with an average of $25.99 \mathrm{~g}$ $100 \mathrm{~g}^{-1}$ (Table 4). According to Grandis et al. (2016), in a study evaluating the use of soybean cake as a substitute for soybean meal, differences in water 
loss under pressure were not also verified, with

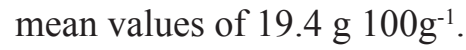

The texture can be considered moderately soft, with average values of $5.4 \mathrm{~kg}-\mathrm{f}$ (Table 4$)$, since meat with shear force between 5.9 and $7.2 \mathrm{~kg}$-f is classified as hard, between 4.1 and $5.4 \mathrm{~kg}-\mathrm{f}$ is moderately soft , and between 2.3 and $3.6 \mathrm{~kg}-\mathrm{f}$ is considered as soft (BOLEMAN et al., 1997). Fernandes Junior et al. (2013) studied increasing levels of sunflower cake in confined lambs, and found shear force of 2.2 to $2.8 \mathrm{~kg}$-f. The values found are close to that of Gomes et al. (2011), that studied two crude glycerin levels in lambs' diet (15 and 30\%), and found values of 5.07 and $5.27 \mathrm{Kg}$-f, respectively, for shear force of the Longissimus dorsi muscle, with no significant difference among the treatments.

There was no significant effect $(\mathrm{P}>0.05)$ for the variables water losses on thawing (WLT) and cooking losses (CL) with averages: 5.68 and 28.33 g $100 \mathrm{~g}^{-1}$ (Table 4), respectively. In similar research,
Lage et al. (2010) testing different levels of crude glycerin in lambs' finishing diet $(0,3,6,9$ and

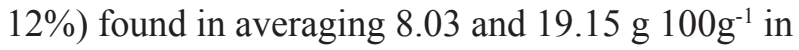
WLT and CL respectively. According to Pardi et al. (2001), the weight loss in cooking is an important quality characteristic associated to meat yield at the time of consumption, and can be affected by the water meat holding capacity. In this study, as water holding capacity was not different among treatments, so the cooking losses were not different either.

About the sensory evaluation (Table 5), there was a linear decrease in odor values $(\mathrm{P}<0.05)$ due to the addition of glycerin. Odor is also an important attribute when purchasing a product. According to Madruga (1997), the meat odor and taste are directly associated with the muscle fat content; although significant differences were observed for the attribute odor, the meat fat content (total lipids) did not differ among treatments (Table 3).

Table 5. Means and standard error values of sensory parameters of meat of lambs terminated in confinement fed with different levels of crude glycerin.

\begin{tabular}{lccccccc}
\hline \multirow{2}{*}{\multicolumn{1}{c}{ Parameters }} & \multicolumn{2}{c}{ Glycerin levels in the diet in replacement of corn (\%) } & \multirow{2}{*}{ Equation } & \multirow{2}{*}{$\mathrm{R}^{2}$} & \multirow{2}{*}{$\mathrm{P}$} \\
\cline { 2 - 6 } & 0 & 7 & 14 & 21 & & & \\
\hline Odor & $3.09 \pm 0.31$ & $2.27 \pm 0.23$ & $2.00 \pm 0.33$ & $2.18 \pm 0.18$ & $3.09-0.16 \mathrm{X}$ & 0.12 & 0.001 \\
Flavor & $1.82 \pm 0.44$ & $2.00 \pm 0.42$ & $2.82 \pm 0.79$ & $2.09 \pm 0.18$ & 2.12 & - & 0.52 \\
Tenderness & $3.73 \pm 0.52$ & $4.09 \pm 0.63$ & $4.45 \pm 0.47$ & $4.06 \pm 0.46$ & 4.06 & - & 0.62 \\
Juiceness & $3.00 \pm 0.35$ & $3.55 \pm 0.34$ & $2.82 \pm 0.37$ & $3.18 \pm 0.37$ & 3.13 & - & 0.91 \\
Overall acceptance & $5.27 \pm 0.71$ & $5.27 \pm 0.63$ & $4.73 \pm 0.61$ & $5.36 \pm 0.69$ & 5.15 & - & 0.92 \\
\hline
\end{tabular}

$\mathrm{R}^{2}=$ Coefficient of determination; $\mathrm{P}=$ Probability.

No significant differences $(\mathrm{P}>0.05)$ were observed for the attributes flavor, tenderness, juiciness, and overall acceptance among treatments (Table 5); which demonstrated that crude glycerin did not change the properties that alter quality meat. Among the different attributes of meat quality, tenderness has been regarded as the most important factor for the consumer, being decisive for the meat commercial value. This factor is associated with physical and sensory processing during chewing (FREIRE et al., 2010).
As it can be seen in Table 6, 31 fatty acids were detected, with higher proportions for C18:1n9 $(1298.90 \mathrm{mg}), \mathrm{C} 16: 0 \quad(709.07 \mathrm{mg})$ and $\mathrm{C} 18: 0$ $(433.30 \mathrm{mg})$, with percentages of 42.72, 23.07 and $14.35 \%$, respectively. According to Leão et al. (2011), the most abundant saturated acids in lamb are myristic (C14:0), palmitic (C16:0) and stearic acids (C18:0); besides the monounsaturated palmitoleic (C16:1n7) and oleic acids (C18:1n9), and polyunsaturated linoleic (C18:2n6), linolenic (C18:3n3) and arachidonic acids (C20:4n6). 
Barros et al. (2015) studied the addition of crude glycerin in lambs' diet and found 27 fatty acids in meat composition, with greater representation also for oleic acid (18:1n9), stearic acid (18:0), and palmitic acid (16:0), confirming the results of this study. Regarding the monounsaturated fatty acids identified in the meat fat, oleic acid was considered as the monounsaturated fatty acid with higher expression levels in ruminants. This study found a value of $1298.90 \mathrm{mg} \mathrm{g}^{-1}$ lipids for this fatty acid, representing $42.72 \%$ of the total, which is higher than that found by Fernandes et al. (2010), who evaluated the lambs' termination in different termination systems, and found variations of $34.4 \%$ for feedlot animals.

Table 6. Means and standard error values of fatty acids in Longissimus dorsi muscle (mg $100 \mathrm{~g}^{-1}$ muscle) of lambs terminated in confinement fed with different levels of crude glycerin.

\begin{tabular}{|c|c|c|c|c|c|c|}
\hline \multirow{2}{*}{$\begin{array}{l}\text { Fatty Acid } \\
\mathrm{mg} 100 \mathrm{~g}^{-1} \text { muscle }\end{array}$} & \multicolumn{4}{|c|}{ Glycerin levels in the diet in replacement of corn (\%) } & \multirow{2}{*}{$\begin{array}{l}\mathrm{CV} \\
(\%)\end{array}$} & \multirow{2}{*}{ Equation } \\
\hline & 0 & 7 & 14 & 21 & & \\
\hline \multicolumn{7}{|c|}{ Saturated Fatty acids } \\
\hline 12:0 & $3.4 \pm 1.3$ & $2.8 \pm 0.5$ & $2.7 \pm 0.6$ & $2.7 \pm 0.3$ & 65.0 & 2.9 \\
\hline 14:0 & $64.2 \pm 20.1$ & $56.3 \pm 7.03$ & $47.9 \pm 6.37$ & $51.3 \pm 4.98$ & 51.75 & 54.2 \\
\hline 15:0 & $11.1 \pm 3.2$ & $10.2 \pm 1.3$ & $8.8 \pm 0.6$ & $13.2 \pm 1.6$ & 47.8 & 10.8 \\
\hline 16:0 & $800.2 \pm 236.4$ & $700.2 \pm 70.4$ & $621.2 \pm 72.5$ & $736.2 \pm 104.3$ & 44.2 & 709.1 \\
\hline $17: 0$ & $31.9 \pm 7.8^{\mathrm{ab}}$ & $35.9 \pm 3.7^{\mathrm{ab}}$ & $33.5 \pm 2.6^{\mathrm{b}}$ & $58.9 \pm 9.5^{\mathrm{a}}$ & 50.1 & $832+8.1 \mathrm{X}$ \\
\hline 18:0 & $442.3 \pm 130.6$ & $456.8 \pm 46.4$ & $401.8 \pm 36.3$ & $437.3 \pm 81.0$ & 44.1 & 433.3 \\
\hline 20:0 & $11.5 \pm 3.7$ & $7.7 \pm 0.6$ & $7.7 \pm 1.2$ & $10.4 \pm 1.7$ & 59.0 & 9.2 \\
\hline 22:0 & $4.6 \pm 1.2$ & $6.6 \pm 0.6$ & $6.1 \pm 0.9$ & $8.5 \pm 2.2$ & 57.0 & 6.6 \\
\hline 24:0 & $15.5 \pm 5.5$ & $16.2 \pm 2.5$ & $13.9 \pm 1.3$ & $14.9 \pm 2.6$ & 55.0 & 15.0 \\
\hline \multicolumn{7}{|c|}{ Monounsaturate fatty acids } \\
\hline $14: \ln 7$ & $4.3 \pm 1.1$ & $4.2 \pm 0.6$ & $3.8 \pm 0.3$ & $4.5 \pm 0.5$ & 44.7 & 4.2 \\
\hline $14: \ln 9$ & $4.5 \pm 1.5$ & $3.7 \pm 0.5$ & $3.0 \pm 0.4$ & $3.4 \pm 0.4$ & 56.9 & 3.6 \\
\hline $15: \ln 9$ & $15.8 \pm 3.4$ & $20.2 \pm 1.8$ & $16.5 \pm 2.8$ & $13.3 \pm 1.7$ & 48.2 & 16.4 \\
\hline $16: \ln 11$ & $8.3 \pm 3.1$ & $11.35 \pm 0.1$ & $8.1 \pm 2.1$ & $12.2 \pm 3.2$ & 83.7 & 10.1 \\
\hline $16: \ln 7$ & $20.5 \pm 7.3$ & $17.7 \pm 6.5$ & $22.1 \pm 5.3$ & $16.3 \pm 6.6$ & 80.9 & 19.1 \\
\hline $16: \ln 9$ & $33.5 \pm 12.4$ & $36.9 \pm 7.7$ & $25.2 \pm 5.4$ & $43.7 \pm 9.4$ & 70.8 & 34.8 \\
\hline $17: \ln 7$ & $24.1 \pm 7.3$ & $23.9 \pm 4.3$ & $20.1 \pm 1.9$ & $34.8 \pm 5.0$ & 51.8 & 25.9 \\
\hline $18: \ln 7$ & $33.1 \pm 7.3$ & $35.45 \pm 4.0$ & $26.8 \pm 3.1$ & $35.8 \pm 6.4$ & 41.8 & 32.7 \\
\hline $18: \ln 9$ & $1280.7 \pm 309.9$ & $1245.1 \pm 127.9$ & $1167.5 \pm 133.9$ & $1490.8 \pm 236.4$ & 39.1 & 1298.9 \\
\hline $18: 1 \mathrm{t} 9$ & $96.8 \pm 36.1$ & $70.8 \pm 7.8$ & $41.8 \pm 4.5$ & $64.5 \pm 14.1$ & 71.2 & 66.5 \\
\hline $20: \ln 9$ & $2.3 \pm 0.4$ & $2.6 \pm 0.9$ & $1.4 \pm 0.3$ & $1.8 \pm 0.8$ & 89.5 & 2.0 \\
\hline \multicolumn{7}{|c|}{ Polyunsaturated fatty acids } \\
\hline $18: 2 \mathrm{n} 6$ & $128.3 \pm 37.5$ & $164.5 \pm 28.5$ & $81.4 \pm 22.1$ & $138.2 \pm 40.1$ & 65.3 & 126.8 \\
\hline $18: 2 \mathrm{t} 1$ & $3.8 \pm 1.3$ & $3.4 \pm 0.7$ & $2.1 \pm 0.4$ & $3.4 \pm 0.7$ & 70.6 & 3.1 \\
\hline $18: 2 \mathrm{t} 2$ & $3.3 \pm 0.7$ & $3.5 \pm 1.1$ & $2.8 \pm 0.3$ & $3.8 \pm 0.4$ & 56.8 & 3.3 \\
\hline $18: 2 \mathrm{t} 3$ & $5.1 \pm 1.4$ & $5.5 \pm 1.7$ & $3.6 \pm 0.7$ & $5.1 \pm 0.6$ & 71.6 & 4.8 \\
\hline $18: 3 n 3$ & $7.8 \pm 1.5$ & $10.6 \pm 1.8$ & $7.14 \pm 1.1$ & $13.2 \pm 5.5$ & 82.3 & 9.8 \\
\hline $18: 3 \mathrm{n} 6$ & $4.8 \pm 0.5$ & $5.9 \pm 0.7$ & $4.2 \pm 0.5$ & $6.9 \pm 1.4$ & 44.6 & 5.5 \\
\hline $20: 2 \mathrm{n} 6$ & $24.2 \pm 6.4$ & $34.1 \pm 3.3$ & $27.4 \pm 5.1$ & $36.3 \pm 10.3$ & 54.7 & 30.8 \\
\hline $20: 3 n 3$ & $23.5 \pm 4.0$ & $38.3 \pm 10.8$ & $23.2 \pm 2.4$ & $32.1 \pm 11.1$ & 70.1 & 29.4 \\
\hline $20: 4 n 6$ & $3.9 \pm 0.3$ & $4.8 \pm 0.7$ & $3.5 \pm 0.6$ & $4.5 \pm 1.5$ & 53.7 & 4.2 \\
\hline $20: 5 n 3$ & $3.2 \pm 0.6$ & $3.4 \pm 1.1$ & $2.8 \pm 0.6$ & $3.3 \pm 1.9$ & 93.8 & 3.1 \\
\hline $22: 6 n 3$ & $4.5 \pm 0.7$ & $4.8 \pm 0.5$ & $4.3 \pm 0.6$ & $5.3 \pm 1.4$ & 47.5 & 4.7 \\
\hline
\end{tabular}


Oleic acid (18:1n-9) has beneficial effects in human's health. According to a review by Calder (2015), the monounsaturated oleic acid, belonging to the omega 9 family, has been shown to have small lowering effects on cholesterol and LDL cholesterol and blood pressure, may improve glucose control and insulin sensitivity. Also, by systematic review and meta-analysis, Schwingshacki and Hoffmann (2014) showed that higher intake of oleic acid was associated with lower risk of coronary disease, cardiovascular events, and cardiovascular mortality. In contrast, Chowdhury et al. (2014), by metaanalysis considering 32 studies, saw no effect of variation of circulating oleic acid in coronary outcomes. Oleic acid is also used in the body as a preferred source of metabolizable energy for rapid growth, according to Oda et al. (2004).

Thesaturated fattyacids palmitic $(\mathrm{C} 16: 0)$, myristic (C14:0) and lauric (C12:0) represented 23.07, 1.78 and $0.10 \%$ of total fatty acids, in levels of 709.07 , 54.27 and $2.90 \mathrm{mg} 100 \mathrm{~g}^{-1}$ muscle, respectively. Although these fatty acids have important roles in normal cellular and tissue metabolism and function, they also have undesirable effects in human's health by raising total and LDL cholesterol concentrations, and thereare some evidences that these same fatty acids increase coagulation, inflammation, and insulin resistance (CALDER, 2015). Thus, a high exposure to these fatty acids is associated with higher risk of cardiovascular disease, coronary heart disease and type 2 diabets. Fernandes et al. (2010) studied lambs on pasture and confinement, and found no significant difference between both termination systems, with mean levels of $29.4 \%$ of palmitic acid (C16:0), while Costa et al. (2012) has found an average of $25.08 \%$ in Santa Ines lambs fed diets with increasing levels of soybean hulls; both similar to this study with $23.07 \%$ for the same fatty acid.

Stearic acid, which totaled $433.3 \mathrm{mg} 100 \mathrm{~g}^{-1}$ muscle, represented $14.35 \%$ of total fatty acids, has lower potency to raise LDL-cholesterol than other saturated fatty acids, like palmitic, lauric and miristic acids (CALDER, 2015). Chowdhury et al. (2014), by meta-analysis, found no significant effect of blood circulating stearic acid in coronary outcomes, being 1.23 the average of relative risk and 0.93-1.61 the $95 \%$ confidence interval. Also, this fatty acid can be transformed into oleic acid (C18:1) by desaturase enzyme in the lipid metabolism (SINCLAIR, 1993), not influencing blood cholesterol levels.

Significant difference according to the glycerin level in the diet was observed only for the margaric acid (C17:0) with an increasing linear effect,

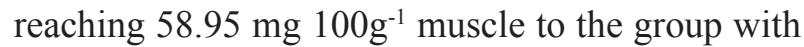
$21 \%$ crude glycerin, corresponding to $1.77 \%$ of total fatty acids (Table 6). Barros et al. (2015) found no effect of increasing glycerin levels on the fatty acid C17:0, with a mean level of $1.65 \%$; however, the maximum level of crude glycerin in diet was $8 \%$.

Odd-chain fatty acids are from the rumen microbial synthesis, mainly, but they can also be produced by synthesis in the animal metabolism, when propionate or valerate is used instead of acetate in the first step of de fatty acid synthesis. Thus, a greater concentration of odd-chain fatty acids in tissues indicate greater availability of propionate in the rumen or blood for the synthesis (SAUVANT; BAS, 2001; MANSBRIDGE; BLAKE, 1997).

In the recent years, the odd-chain fatty acid margaric has gained research interest, mainly because its beneficial effects on the human's health, which include strong inverse association with type 2 diabetes and lower risk of cardiovascular disease and coronary heart disease (CALDER, 2015; JENKINS et al., 2015).

Studies have shown that the omega-3 and omega-6 fatty acids are active in many body functions such as blood pressure control, heart rate, vascular dilation, blood clotting, immune response (CALDER, 2015; MAHAN; ESCOTT-STUMP, 1998), and are considered essential since the human body cannot produce these fatty acids, which should be ingested by the daily diet. 
In this experiment, the lamb meat had $9.8 \mathrm{mg}$ $100 \mathrm{~g}^{-1}$ muscle $(0.35 \%)$ linolenic acid (C18:3 n3), and $126.8 \mathrm{mg}(4.33 \%)$ linoleic acid (C18:2 n6), and these small values can be explained by ruminal biohydrogenation process, which may be partial or complete. Regarding polyunsaturated fatty acids (PUFA), Costa et al. (2012) identified in lamb meat linoleic acid at levels of $4.34 \%$ and linolenic acid, with $0.31 \%$, whose values are close to the findings of this study, 4.33 and $0.35 \%$, respectively.

Conjugated linoleic acid (CLA) accounted for $0.21 \%$ (6.1 mg $100 \mathrm{~g}^{-1}$ muscle) of total lipids (Table
7), suggesting an incomplete biohydrogenation of linoleic acid (C18:2), thus forming the conjugated linoleic acid that is absorbed and deposited in the muscle. This result is desirable, since CLA is an animal origin fatty acid with anticarcinogenic properties, and is associated with lower incidence of cardiovascular diseases, tumors' prevention and treatment (TAPIERO et al., 2002). In a review study, Schmid et al. (2006) observed CLA concentrations in lamb meat ranging from 4.3 to $19 \mathrm{mg} \mathrm{g}^{-1}$ lipids, whereas in this research this value was on average $6.10 \mathrm{mg} \mathrm{g}^{-1}$ lipids.

Table 7. Means and standard error values of saturated fatty acids (SFA), monounsaturated (MUFA) and polyunsaturated (PUFA), and their relations, of lambs terminated in confinement fed with different levels of crude glycerin.

\begin{tabular}{|c|c|c|c|c|c|c|}
\hline \multirow{2}{*}{$\begin{array}{l}\text { Fatty Acid } \\
\text { mg } 100 \mathrm{~g}^{-1} \text { muscle }\end{array}$} & \multicolumn{4}{|c|}{ Glycerin levels in the diet in replacement of corn (\%) } & \multirow{2}{*}{$\begin{array}{l}\text { CV } \\
(\%)\end{array}$} & \multirow{2}{*}{ Equation } \\
\hline & 0 & 7 & 14 & 21 & & \\
\hline SFA $^{1}$ & $1385.1 \pm 398.1$ & $1293.1 \pm 119$ & $1143.8 \pm 105.3$ & $1333.7 \pm 195.1$ & 41.5 & 1282.1 \\
\hline MUFA $^{2}$ & $1425.2 \pm 332.8$ & $1398.7 \pm 133.1$ & $1293.4 \pm 138.3$ & $1655.3 \pm 249.2$ & 37.3 & 1445.9 \\
\hline PUFA $^{3}$ & $212.9 \pm 48.5$ & $279.2 \pm 35.4$ & $162.8 \pm 31.1$ & $252.5 \pm 70.2$ & 54.7 & 226.0 \\
\hline$n 3^{4}$ & $39.1 \pm 5.85$ & $57.2 \pm 10.9$ & $37.6 \pm 4.4$ & $53.9 \pm 16.9$ & 58.0 & 47.1 \\
\hline$n 6^{5}$ & $161.5 \pm 4.2$ & $209.5 \pm 31.1$ & $116.6 \pm 26.3$ & $186.1 \pm 52.9$ & 58.9 & 167.5 \\
\hline Ratio N6:N3 & $4.0 \pm 0.6$ & $4.13 \pm 0.6$ & $3.1 \pm 0.5$ & $3.8 \pm 0.5$ & 38.2 & 3.7 \\
\hline PUFA:SFA & $0.18 \pm 0.03$ & $0.2 \pm 0.02$ & $0.1 \pm 0.02$ & $0.2 \pm 0.04$ & 45.4 & 0.1 \\
\hline CLA $^{6}$ C9T11 & $2.5 \pm 0.8$ & $1.8 \pm 0.5$ & $1.9 \pm 0.2$ & $1.9 \pm 0.4$ & 79.0 & 2.0 \\
\hline CLA t10 c12 & $4.0 \pm 0.4$ & $5.1 \pm 1.2$ & $3.3 \pm 0.4$ & $3.9 \pm 1.4$ & 63.7 & 4.0 \\
\hline CLA TOTAL & $6.5 \pm 1.2$ & $6.8 \pm 1.5$ & $5.2 \pm 0.6$ & $5.8 \pm 1.2$ & 56.3 & 6.1 \\
\hline TRANS TOTAL & $109.1 \pm 38.8$ & $83.3 \pm 9.1$ & $50.4 \pm 5.8$ & $77.1 \pm 14.4$ & 65.8 & 77.8 \\
\hline
\end{tabular}

${ }^{1} \mathrm{SFA}=$ saturated fatty acids; ${ }^{2} \mathrm{MUFA}=$ monounsaturated fatty Acids; ${ }^{3} \mathrm{PUFA}=$ polyunsaturated fatty acids; ${ }^{4} \mathrm{n} 3=\mathrm{Omega}-3 ;{ }^{5} \mathrm{n} 6=$ Omega-6; ${ }^{6} \mathrm{CLA}=$ Conjugated Linoleic Acid.

The values found for the polyunsaturated: saturated fatty acids ratio (PUFA:SFA) in this study (0.19) were lower than those recommended for a healthy diet as reported by the Ministry of Health of the United Kingdom that should be greater than 0.4 (WOOD et al., 2003), which is also recommended by the Department of Health (1994) which is 0.45 in foods. However, according to the literature, this ratio in meat is generally low, around 0.1 (SCOLLAN et al., 2005) characterizing the products derived from ruminant animals, which have a ratio of PUFA:SFA fatty acids lower due to the biohydrogenation of dietary unsaturated fatty acids by rumen bacteria (BANSKALIEVA et al., 2000). These results demonstrate that sheep meat has higher levels of saturated fatty acids and fewer rates of polyunsaturated: saturated fatty acids.

The $\mathrm{n} 6: \mathrm{n} 3$ ratio did not change $(\mathrm{P}>0.05)$ as a function of the levels of crude glycerin (Table 7), being on average 3.74. Simionatto et al. (2011) reported that nutritionists have emphasized the importance of maintaining a good ratio of n6:n3 levels below 4 for reducing the risk of developing cancer or possible coronary complications, especially blood clots, leading to heart attacks (ENSER, 2001). On the other hand, diets containing 
high amounts of fatty acids of the $\mathrm{n} 6$ series, or ratio n6:n3 above 4 (DEPARTMENT OF HEALTH, 1994) can increase the production of thromboxanes and leukotrienes which, in excess, are related to several diseases such as thrombosis, arrhythmias, arthritis, asthma, and psoriasis (TAPIERO et al., 2002). Therefore, the lamb meat is more favorable to human health because of its low n6:n3 ratio $(2: 1)$ (WOOD et al., 2003).

\section{Conclusions}

The use of glycerin in the diet for finishing lambs does not alter the meat characteristics, maintaining the product quality for consumption. The main fatty acids in lamb meat were not affected by increasing levels of crude glycerin in diet, providing a satisfactory result for conjugated linoleic acid (CLA); and the ratio n-6:n-3 remained at levels below 4 .

\section{References}

ALVES, L. G. C.; FERNANDES, A. R. M.; OSÓRIO, J. C. S.; OSÓRIO, M. T. M.; NUBIATO, K. E. Z.; CUNHA, C. M.; CORNÉLIO, T. C.; CATALANO NETO, A. P. Composição de ácidos graxos na carne de cordeiro em confinamento. Pubvet, Maringá, v. 6, n. 32, p. 1-15, 2012.

AMERICAN MEAT SCIENCE ASSOCIATION AMSA. Meat evaluation handbook. Champaign: American Meat Science Association, 2001. 160 p.

Research guideliness for cookery sensory and instrumental tenderness measurement of fresh meat. Chicago: American Meat Science Association, 1995. 48 p.

APPLE, J. K.; DIKEMAN, M. E.; MINTON, J. E.; McMURPHY, R. M.; FEDDE, M. R.; LEIGHT, D. E.; UNRUH, J. A. Effects of restrain and isolation stress and epidural blockade on endocrine and blood metabolite status, muscle glycogen metabolism, and indice of darckcutting longissimus muscle of sheep. Journal of Animal Science, Champaign, v. 73, n. 8, p. 2295-2307, 1995.

ASSOCIAÇÃO BRASILEIRA DE NORMAS TÉCNICAS - ABNT. Análise sensorial dos alimentos e bebidas: terminologia. NBR 12806. São Paulo: ABNT, 1993.
ASSOCIATION OF OFFICIAL ANALYTICAL CHEMISTS - AOAC. Official methods of analysis. $18^{\text {th }}$ ed. Washington: AOAC International, 2005.

AVILA, J. S.; CHAVES, A. V.; HERNANDEZ-CALVA, M.; BEAUCHEMIN, K. A.; MCGINN, S. M.; WANG, Y.; HARSTAD, O. M.; MCALLISTER, T. A. Effects of replacing barley grain in feedlot diets with increasing levels of glycerol on in vitro fermentation and methane production. Animal Feed Science and Technology, Amsterdam, v. 166-167, p. 265-268, 2011.

BANSKALIEVA, V.; SAHLU, T.; GOETSCH, A. L. Fatty acid composition of goat muscles and fat depots: a review. Small Ruminant Research, Amsterdam, v. 37, n. 3, p. 255-268, 2000.

BARROS, M. C. C.; SILVA, F. F.; SILVA, R. R.; SIMIONATO, J. I.; GUIMARÃES, G. S.; SILVA, L. L.; FACURI, L. M. A. M. Glicerina bruta na dieta de ovinos confinados: composição centesimal e perfil de ácidos graxos do longissimus dorsi. Semina: Ciências Agrárias, Londrina, v. 36, n. 1, p. 431-442, 2015.

BERGNER, H.; KIJORA, C.; CERESNAKOVA, Z.; SZAKACS, J. In vitro studies on glycerol transformation by rumen microorganisms. Archiv für Tierernährung, Berlin, v. 48, n. 1, p. 245-256, 1995.

BLIGH, E. G.; DYER, W. J. A. Rapid method of total lipid extraction and purification. Canadian Journal of Biochemistry and Physics, Ottawa, v. 37, n. 52, p. 911917, 1959.

BOLEMAN, S. J.; BOLEMAN, S. L.; MILLER, R. K.; TAYLOR, J. F.; CROSS, H. R.; WHEELER, T. L.; KOOHMARAIE, M.; SHACKELFORD, S. D.; MILLER, M. F.; JOHNSON, D. D.; SAVELL, J. W. Consumer evaluation of beef of know categories of tenderness. Journal of Animal Science, Champaign, v. 75, n. 6, p. 1521-1524, 1997.

BRESSAN, M. C.; PRADO, O. V.; PÉREZ, J. R. O.; LEMOS, A. L. S. C.; BONAGURIO, S. Efeito do peso ao abate de cordeiros Santa Inês e Bergamácia sobre as características físico-químicas da carne. Ciência e Tecnologia de Alimentos, Campinas, v. 21, n. 3, p. 293303, 2001.

CALDER, P. C. Functional roles of fatty acids and their effects on human health. Journal of Parenteral and Enteral Nutrition, Champaign, v. 39, p. 18S-32S, 2015. Supplement 1.

CAÑEQUE, V.; SAÑUDO, C. Metodología para el studio de la calidad de la canal y de la carne en rumiantes. Madri: INIA, 2000. 255 p. 
CHOWDHURY, R.; WARNAKULA, S.; KUNUTSOR, S.; CROWE, F.; WARD, H. A.; JOHNSON, L.; FRANCO, O. H.; BUTTERWORTH, A. S.; FOROUHI, N. G.; THOMPSON, S. G.; KHAW, K. T.; MOZAFFARIAN, D.; DANESH, J.; DI ANGELANTONIO, E. Association of dietary, circulating, and supplement fatty acids with coronary risk: a systematic review and meta-analysis. Annals of Internal Medicine, Philadelphia, v. 160, n. 6, p. 398-406, 2014.

COSTA, L. S.; SILVA, R. R.; SILVA, F. F.; CARVALHO, G. G. P.; SIMIONATO, J. I.; MARQUES, J. A.; SILVA, V. L.; SAMPAIO, C. B. Centesimal composition and fatty acids of meat from lambs fed diets containing soybean hulls. Revista Brasileira de Zootecnia, Viçosa, MG, v. 41, n. 7, p. 1720-1726, 2012.

DEPARTMENT OF HEALTH. Report on health and social subjects $n^{\circ} 46$. Nutritional aspects of cardiovascular disease. London: HMSO, 1994.

ENSER, M. The role of fats in human nutrition. In: ROSSELL, B. (Ed.). Animal carcass fats. Oils and fats. Leatherhead, Surrey: Leatherhead Publishing, 2001. p. $77-122$

FERNANDES JUNIOR, F. F.; RIBEIRO, E. L. A., MIZUBUTI, I. Y.; SILVA, L. D. F.; BARBOSA, M. A. A. F.; PRADO, O. P. P., PEREIRA, E. S.; PIMENTEL, P. G.; CONSTANTINO, C. Características de carcaça e qualidade da carne de cordeiros Santa Inês alimentados com torta de girassol em substituição ao farelo de algodão. Semina: Ciências Agrárias, Londrina, v. 34, n. 6, p. 3999-4014, 2013. Suplemento 2.

FERNANDES, M. A. M.; MONTEIRO, A. L. G.; POLI, C. H. E. C.; BARROS, C. S.; ALMEIDA, R.; RIBEIRO, T. M. D. Composição tecidual da carcaça e perfil de ácidos graxos da carne de cordeiros terminados a pasto ou em confinamento. Revista Brasileira de Zootecnia, Viçosa, MG, v. 39, n. 7, p. 1600-1609, 2010.

FREIRE, A. M. T.; NAKAO, M. Y.; GUERRA, C. C.; CARRER, C. C.; SOUZA, S. C.; TRINDADE, M. A. Determinação de parâmetros físico-químicos e de aceitação sensorial da carne de cordeiros proveniente de diferentes tipos raciais. Alimentos e Nutrição, Araraquara, v. 21, n. 3, p. 481-486, 2010.

FRENCH, P.; STANTON, C.; LAWLESS, F.; O'RIORDAN, E. G.; MONAHAN, F. J.; CAFFREY, P. J.; MOLONEY, A. P. Fatty acid composition, including conjugated linoleic acid, of intramuscular fat from steers offered grazed grass, grass silage or concentrate based diets. Journal of Animal Science, Champaign, v. 78, n. 11, p. 2849-2855, 2000.
GOMES, M. A. B.; MORAES, G. V.; MATAVELI, M.; MACEDO, F. A. F.; CARNEIRO, C. T.; ROSSI, M. R. Performance and carcass characteristics of lambs fed on diets supplemented with glycerin from biodiesel production. Revista Brasileira de Zootecnia, Viçosa, MG, v. 40, n. 10, p. 2211-2219, 2011.

GRANDIS, F. A.; RIBEIRO, E. L. A.; MIZUBUTI, I. Y.; BUMBIERIS JUNIOR, V. H.; PRADO, O. P. P.; PINTO, A. P. Características de carcaça e qualidade da carne de cordeiros alimentados com diferentes teores de torta de soja em substituição ao farelo de soja. Ciência Animal Brasileira, Goiânia, v. 17, n. 3, p. 327-341, 2016.

HOUBEN, J. H.; VAN DIJK, A.; EIKELENBOOM, G.; HOVING-BOLINK, A. H. Effect of dietary vitamin E supplementation, fat level and packaging on color stability and lipid oxidation in minced beef. Meat Science, Barking, v. 55, n. 3, p. 331-336, 2000.

JENKINS, B.; WEST, J. A.; KOULMAN, A. A review of odd-chain fatty acid metabolism and the role of pentadecanoic acid (C15:0) and heptadecanoic acid (C17:0) in health and disease. Molecules, Tongzhou, v. 20, n. 2, p. 2425-2444, 2015.

KRISTENSEN, N. B.; RAUN, B. M. L. Ruminal fermentation, portal absorption, and hepatic metabolism of glycerol infused into the rumen of lactating dairy cows. In: INTERNATIONAL SYMPOSIUM ON ENERGY AND PROTEIN METABOLISM AND NUTRITION, 2., 2007, Vichy. Proceedings... Vichy: Wageningen Academic Publishers, 2007. p. 355-356.

LAGE, J. F.; PAULINO, P. V. R.; PEREIRA, L. G. R.; VALADARES FILHO, C. S.; OLIVEIRA, S. A.; DETMANN, E.; SOUZA, P. K. N.; LIMA, M. C. J. Glicerina bruta na dieta de cordeiros terminados em confinamento. Pesquisa Agropecuária Brasileira, Brasília, v. 45, n. 9, p. 1012-1020, 2010.

LEÃO, A. G.; SILVA SOBRINHO, A. G.; MORENO, G. M. B.; SOUZA, H. A.; PEREZ, H. L.; LOUREIRO, C. M. B. Características nutricionais da carne de cordeiros terminados com dietas contendo cana-de-açúcar ou silagem de milho e dois níveis de concentrado. Revista Brasileira de Zootecnia, Viçosa, MG, v. 40, n. 5, p. 10721079, 2011.

MADRUGA, M. S. Revisão: formação do aroma cárneo. Boletim da Sociedade Brasileira de Ciência e Tecnologia de Alimentos, Campinas, n. 31, v. 1, p. 33-41, 1997.

MAHAN, L. K.; ESCOTT-STUMP, S. Krause: alimentos, nutrição e dietoterapia. 9. ed. São Paulo: Roca, 1998. $1165 \mathrm{p}$. 
MAIA, E. L.; RODRIGUEZ-AMAYA, D. B. Avaliação de um método simples e econômico para a metilação de ácidos graxos com lipídios de diversas espécies de peixes. Revista do Instituto Adolfo Lutz, São Paulo, v. 53, n. 1-2, p. 27-35, 1993.

MANSBRIDGE, R. J.; BLAKE, J. S. Nutritional factors affecting the fatty acid composition of bovine milk. British Journal of Nutrition, London, v. 78, n. 1, p. 37S-47S, 1997.

MIZUBUTI, I. Y.; PINTO, A. P.; PEREIRA, E. S.; RAMOS, B. M. O. Métodos laboratoriais de avaliação de alimentos para animais. Londrina: EDUEL, 2009. $228 \mathrm{p}$.

NATIONAL RESEARCH COUNCIL - NRC. Nutrient requirements of small ruminants. Washington: National Academy Press, 2007.

ODA, S. H. I.; BRESSAN, M. C.; CARDOSO, M. G.; FREITAS, R. T. F.; MIGUEL, G. Z.; FARIA, P. B.; SAVIAN, T. V.; KABEYA, D. M. Efeito do método de abate e do sexo sobre a qualidade da carne de capivara (Hydrochaeris hydrochaeris). Ciência e Tecnologia de Alimentos, Campinas, v. 24, n. 3, p. 236-242, 2004.

ORTIZ, S. J.; COSTA, C.; GARCIA, A. C.; SILVEIRA, A. V. L. Efeito de diferentes níveis de proteína bruta na ração sobre o desempenho e as características de carcaça de cordeiros terminados em creep feeding. Revista Brasileira de Zootecnia, Viçosa, MG, v. 34, n. 6, p. 23822389, 2005.

OSÓRIO, J. C. S.; OSÓRIO, M. T. M. Cadeia produtiva e comercial da carne de ovinos e caprinos qualidade e importância dos cortes. In: SIMPÓSIO INTERNACIONAL SOBRE OVINOS E CAPRINOS, 2003, João Pessoa. Anais... João Pessoa: EMEPA, 2003. p. 403-416.

PARDI, M. C.; SANTOS, I. F.; SOUZA, E. R.; PARDI, H. S. Ciência, higiene e tecnologia da carne. 2. ed. ver. amp. Goiânia: Editora UFG, 2001. v. 1, 624 p.

PONNAMPALAM, E. N.; SINCLAIR, A. J.; EGAN, A. R.; BLAKELEY, S. J.; LEURY, B. J. Effect of diets containing $n-3$ fatty acids on muscle long chain n-3 fatty acid content in lambs fed low- and medium- quality roughage diets. Journal of Animal Science, Champaign, v. 79 , n. 3, p. 698-706, 2001.

PRATA, L. F.; FUKUDA, R. T. Fundamentos da higiene e inspeção de carnes. Jaboticabal: FUNEP, 2001. 349 p.

SAÑUDO, C. La calidad organoléptica de la carne con especial referencia a la especie ovina. Factores que la determinan, métodos de la medida y causas de variación.
Zaragoza: Facultad de Veterinaria - Departamento Producción Animal y Ciencia de los Alimentos, 1992. $117 \mathrm{p}$.

SAUVANT, D.; BAS, P. La digestion des lipids chez ruminant. INRA Productions Animales, Paris, v. 14, n. 5, p. 303-310, 2001.

SCHMID, A.; COLLOMB, M.; SIEBER, R.; BEE, G. Conjugated linoleic acid in meat and meat products: a review. Meat Science, Barking, v. 73, n. 1, p. 29-41, 2006.

SCHWINGSHACKI, L.; HOFFMANN, G. Adherence to Mediterranean diet and risk of cancer: a systematic review and meta-analysis of observational studies. International Journal of Cancer, Heidelberg, v. 135, n. 8, p. 1884-1897, 2014.

SCOLLAN, N. D.; DEWHURST, R. J.; MOLONEY, A. P. Improving the quality of products from grassland. In: INTERNATIONAL GRASSLAND CONGRESS, 2005, Dublin. Proceedings... Dublin: International Grassland Congress, 2005. p. 23, 41-56.

SIMIONATTO, J. I.; COSTA, L. S.; SILVA, R. R.; MACEDO, M. S.; LIRA, A. P.; LACERDA, E. C. Q. Relação Ômegas 6 e 3 em ovinos da raça Santa Inês alimentados com diferentes níveis de inclusão de casca de soja em substituição ao milho. Revista Científica de Produção Animal, Salvador, v. 13, n. 1, p. 111-114, 2011.

SINCLAIR, A. J. Dietary fat and cardiovascular disease: the significance of recent developments for the food industry. Food Australia, North Sydney, v. 45, n. 5, p. 226-231, 1993.

SOUSA, D. L.; PIMENTEL, P. G.; SILVA, E. M. C.; PEREIRA, E. S.; MONTENEGRO, A. R.; CAMPOS, A. C. N.; MIZUBUTI, I. Y.; SANTOS, A. A. Meat quality of castrated and non-castrated Santa Ines lambs subjected to food restriction. Semina: Ciências Agrárias, Londrina, v. 37, n. 3, p. 1515-1526, 2016.

STATISTICAL ANALYSIS SYSTEMS INSTITUTE SAS. SAS user's guide: Statistics Version 2002. Cary: SAS, 2002.

TAPIERO, H.; NGUYEN, B.; COUVREUR, P. Polyunsaturated fatty acids (PUFA) and eicosanoids in human health and pathologies. Biomedicine and Pharmacotherapy, Paris, v. 56, n. 5, p. 215-222, 2002.

VIANA, J. G. A.; REVELLION, P. P. J.; SILVEIRA, P. C. V. Alternativa de estruturação da cadeia de valor da ovinocultura no Rio Grande do Sul. Revista Brasileira de Gestão e Desenvolvimento Regional, Taubaté, v. 9, n. 1, p. 187-210, 2013.

WARRIS, P. D. Ciencia de la carne. Zaragoza: Acribia, 2003. $309 \mathrm{p}$. 
WHIPPlE, G.; KOOHMARAIE, M.; DIKEMAN, M. ZEOLA, L. B. M. N.; SILVA SOBRINHO, A. G.; E.; CROUSE, J. D.; HUNT, M. C.; KLEMM, K. D. GONZAGANETO, S.; MARQUES, T.A. C. Composição Evaluation of attributes that affect Longissimus muscle centesimal da carne de cordeiros submetidos a dietas tenderness in Boss taurus and Boss indicus cattle. Journal com diferentes teores de concentrado. Ciência Rural, of Animal Science, Champaign, v. 68, n. 9, p. 2716-2728, Santa Maria, v. 34, n. 1, p. 253-257, 2004. 1990.

WOOD, J. D.; RICHARDSON, R. I.; NUTE, G. R.; FISHER, A. V.; CAMPO, M. M.; KASAPIDOU, E.; SHEARD, P. R.; ENSER, M. Effects of fatty acids on meat quality: a review. Meat Science, Barking, v. 66, n. 1, p. 21-32, 2003. 